\title{
磁気セイルの推力特性に関する実験研究*1 Thrust Evaluation of Magnetic Sail in Laboratory
}

\author{
上野一磨*2,*3 · 塩裕 哉*2 船木一幸*4 \\ Kazuma Ueno, Yuya Oshio, Ikkoh Funaki, Hiroshi Yamakawa and Hideyuki Horisawa
}

Key Words : Spacecraft Propulsion, Magnetic Sail, Thrust Measurement, Magnetosphere, Scale Model Experiment

\begin{abstract}
Magnetic Sail is one of in-space propulsion systems using the interaction between the solar wind and an artificial magnetic field. In order to reveal thrust performance of Magnetic Sail which has feasible scale of magnetosphere, scale model experiment of Magnetic Sail was conducted in laboratory using Magnetic Sail ground simulator which was arranged in the space science chamber at JAXA. Magnetic Sail scale model obtains magnetospheric size of $L=0.07 \mathrm{~m}$, and $0.47 \mathrm{~N}$-thrust in laboratory. Also, thrust is increased by increasing of the magnetic moment of a coil. The scale model corresponds to $30-\mathrm{N}$-class magnetic-sail which produces $80 \mathrm{~km}$-size magnetosphere in space.
\end{abstract}

\section{記 号の 説 明}

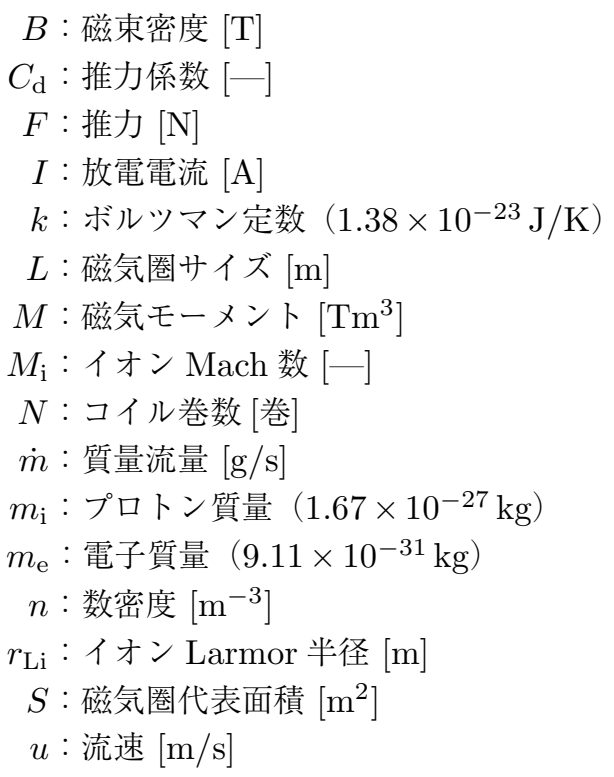

\section{1. は じめ に}

ソーラーセイルに代表される太陽エネルギーを電力に変 換することなく推力を得る推進システムは, 既存の電気推 進システムに比べ, 探査機への推進剤積載量を低減できる ことから, 推力重量比において優位であり, 木星以遠深宇宙 探査用推進システムとして注目されている。ソーラーセイ ルが利用する太陽光の他に, 宇宙推進に利用可能な太陽工 ネルギーとして太陽風が挙げられる。太陽風は太陽由来の

\footnotetext{
*1 (C) 2011 日本航空宇宙学会

平成 22 年 8 月 3 日原稿受付

*2 総合研究大学院大学物理科学研究科

*3 現 宇宙航空研究開発機構

*4 宇宙航空研究開発機構宇宙科学研究所

*5 京都大学生存圈研究所

$* 6$ 東海大学工学部
}

高速プラズマ流であり，太陽から $1 \mathrm{AU}$ において $400 \mathrm{~km} / \mathrm{s}$ もの速度で吹いていることが知られている。この太陽風を 受け止めることでヨットのように風に吹かれて推進するの が磁気セイル（Magnetic Sail, MagSail）である.

磁気セイルは宇宙機に搭載した超伝導コイルによって宇 宙機周りに磁場を展開する。 太陽風プラズマは展開された コイル磁場と干渉し, 磁気圈と呼ばれる磁場領域を形成する (第 1 図). 磁気圈としてょく知られているものには, 地球磁 場と太陽風との干涉によって生じる地球磁気圈があるが, 磁 気セイルでは, 宇宙機周りに形成した人工磁気圈によって太 陽風を受け止め, 推進力を得る。本コンセプトは 1990 年に アメリカのZubrin らによって提案され，注目を集めた1 13). しかし, 十分な推力を得るには直径数十 $\mathrm{km}$ ものコイルが必 要であることから，実用化には至らなかった，その後，プラ ズマ噴射による磁場展開をアシストする手法が Winglee ら によって提案され, mini-magnetospheric plasma propulsion（M2P2）と名付けられた4). 現在は日本の JAXAを 中心とした研究グループが磁気プラズマセイル (MPS) と して研究を行っている. 数值解析によるアプローチでは, 磁 気セイルの推進性能は明らかにされ5〜7), 現在はプラズマ 噴射による磁場展開のアシストについての研究が盛んに行 われている ${ }^{8,9)}$. しかし, 複雑な物理現象のため, 磁気プラ ズマセイルは現在も明確な設計指針が得られていない.

実験によるアプローチでは Winglee らによって M2P2 の実験室実験が行われたが10), 推力評価には至っていない. 我々は磁気プラズマセイルの推力評価を行うことを前提と して, 最もシンプルな磁気セイルについて実験による推力 評価を行っている11 15). 磁気セイル磁気圈サイズに対する 理論推力を第 2 図に示す。これまでに磁気圈サイズ $720 \mathrm{~km}$ 程度の比較的大きな磁気圈について推力評価を行い, その 性能を明らかにした ${ }^{14,15)}$. 本研究では深宇宙探査機として 磁気プラズマセイルが目標とする $1 \mathrm{~N}$ クラスの推進性能を 持つ磁気セイル（磁気圈サイズ $L=\sim 20 \mathrm{~km}$ ）の推進性能 


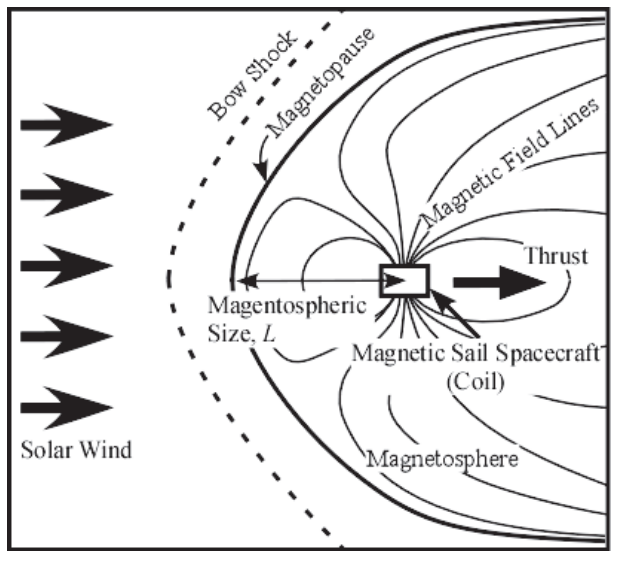

第1図＼cjkstart磁気セイル周りのプラズマ流れと磁場構造の想像図

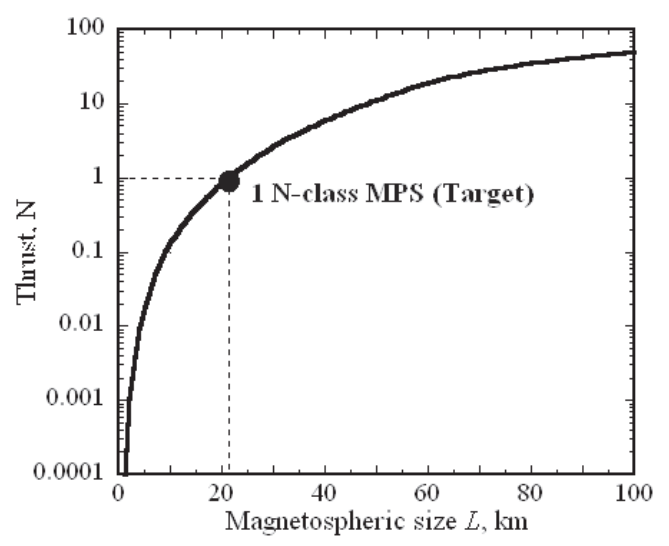

第 2 図 推力と磁気圈サイズの関係

を評価するため, 磁気圈サイズ $20 \mathrm{~km}<L<100 \mathrm{~km}$ のス ケールモデル実験を行い, 推力の直接計測を行った.

\section{2. 磁気セイルの推力}

太陽風は太陽の重力を振り切って噴出した荷電粒子（イ オン・電子) で構成される。荷電粒子は宇宙機に搭載した 超伝導コイルが生成する磁場と干渉し, $u \times B$ のローレン ツ力によって, 太陽風プラズマの流れは妨げられ, 太陽風 は運動量を失う。太陽風が失った運動量は電磁気的な伝達 によってコイルに伝わることで推進力が発生する。このと きコイルに伝わる力 $F$ は物体が一様流中で受ける抗力と同 様に以下の式で表すことができる.

$$
F=C_{\mathrm{d}} \frac{1}{2} n m_{\mathrm{i}} u_{\mathrm{sw}}{ }^{2} \pi L^{2}
$$

ここで, $n m_{\mathrm{i}} u_{\mathrm{sw}}{ }^{2} / 2$ は太陽風の動圧を, $\pi L^{2}$ は太陽風を受 け止める代表面積を表し, 一般的に抗力係数として用いる $C_{\mathrm{d}}$ を本研究では推力係数として用いる ${ }^{11)}$. 本研究では磁 気圈サイズを宇宙機（コイル）中心から太陽風上流方向の 磁気圈の端までの距離で定義し, これを代表長 $L$ とする. コイル磁場をダイポール磁場で近似した場合, この代表長 $L$ は磁気圈の位置が太陽風動圧とコイルの作る磁気圧の釣 り合う位置として以下の式で表すことができる.

$$
L=\left(\frac{M^{2}}{8 \mu_{0} \pi^{2} n m_{\mathrm{i}} u_{\mathrm{sw}}{ }^{2}}\right)^{1 / 6}
$$

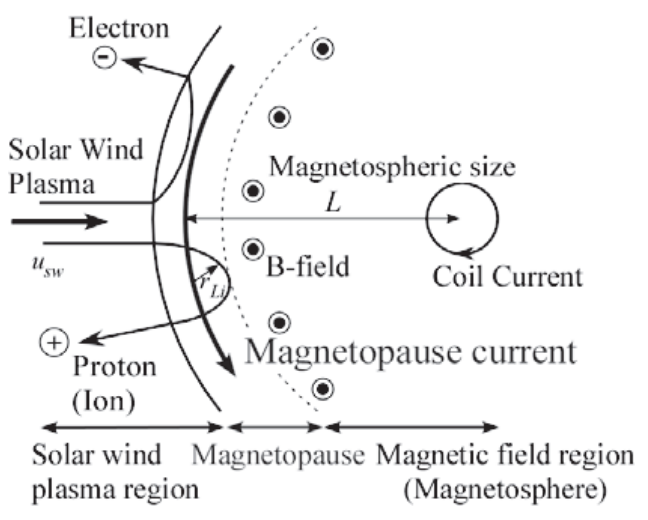

第 3 図＼cjkstart磁気圈境界面における荷電粒子の挙動

ここで $M$ はコイル磁気モーメント， $\mu_{0}$ は真空の透磁率を 表す。式 (2)では, 太陽風の動圧が静圧に比べ圧倒的に大 きいこと, また, 荷電粒子が磁場によって $180^{\circ}$ 方向を変え られるような完全弾性衝突の場合, 動圧 $\varepsilon n m_{\mathrm{i}} u_{\mathrm{sw}}{ }^{2} / 2$ にお ける運動量交換の係数が $\varepsilon=2$ であることを用いた ${ }^{16)}$.

この式からわかるように磁気圈サイズ $L$ は太陽風動圧 が与えられる量であることから, 磁気モーメント $M$ のみ で決まる，つまり，コイルの巻数 $N$, コイルに流す電流值 $I_{\text {coil }}$, コイルの面積 $S_{\text {coil }}$ で決まる磁気モーメント $M=$ $\mu_{0} N I_{\text {coil }} S_{\text {coil }}$ に対して磁気サイズ $L$ は $L \propto M^{1 / 3}$ であり, 推力に比例する磁気圈代表面積 $S$ には $S \propto M^{2 / 3}$ となる.

磁気セイルの推力 $F$ を制御するためには, 磁気圈代表面 積 $S$ と推力係数 $C_{\mathrm{d}}$ の関係を明らかにする必要がある。これ までの研究によって推力係数 $C_{\mathrm{d}}$ は磁気圈代表面積を決める 磁気圈サイズ $L$ と磁気圈境界面におけるイオンの Larmor 半径 $r_{\mathrm{Li}}$ との比によって決まることが数值解析によって示 されている ${ }^{6}$. 第 3 困に磁気圈境界面の構造と磁気圈サイ ズ $L$ の関係を示す．磁気セイルがプラズマをブロックする ために物理的な壁ではなく, 磁場との干涉を利用している ため, 磁気圏に侵入してきたイオン粒子は Larmor 半径で 曲げられる。このとき, 電子はイオンより軽いため, より 小さな半径でイオンとは逆向きに曲げられる。 これにより, 磁気圈境界面には境界面電流が誘起される。磁気セイルの 推力はこの境界面電流が作る磁場とコイル電流の間に生じ るローレンツカによって生じるともいえる。

この磁気圈境界面におけるイオン Larmor 半径 $r_{\mathrm{Li}}$ と磁 気圈サイズ $L$ との比が $r_{\mathrm{Li}} / L \ll 1$ である場合, その境界層 厚さは無視することができ, 太陽風にとって磁気圈は壁の ように振る舞う。結果として, 効率よくプラズマを受け止 められるため, $C_{\mathrm{d}}$ も大きくなる. それに対し, $r_{\mathrm{Li}} / L>1$ である場合, 太陽風荷電粒子は磁気圈サイズ $L$ よりも大き い半径で曲げられるため, 太陽風は磁場の影響をほとんど 受けずに通過する．故に $C_{\mathrm{d}}$ は小さくなる，太陽からの距 離が $1 \mathrm{AU}$ (太陽から地球までの距離）における太陽風パ ラメータから磁気圈境界面におけるイオン Larmor 半径は $r_{\mathrm{Li}}=72 \mathrm{~km}$ であり, 効率的に太陽風を受け止めるためには 数十 $\mathrm{km}$ 以上の磁気圈サイズを実現することが必要となる.

こうしたことから, 磁気セイルの推力は式 (1) から磁気 
圈サイズ $L$ を大きくすることで太陽風を効率的に受けて推 力が大きくなるということがわかる.

\section{3. 磁気セイル地上シミュレータ}

太陽風の特性を第 1 表にまとめた。太陽風は超高速，か つ希薄なプラズマ流であり，太陽風を受け止めて得られる 力は太陽から $1 \mathrm{AU}$ において $7 \times 10^{-10} \mathrm{~N} / \mathrm{m}^{2}$ 程度となる。 実際の太陽風と同一のプラズマを実験室内で生成した場合, 推力の計測が可能な力を発生させるには $10^{-6} \mathrm{~N}$ 以上は必 要であることから, 大径の模擬太陽風とそれに対して十分 大きな真空チャンバーが必要となる。そこで，本実験では 高速, 高密度のプラズマ流を太陽風とすることで, 実験室 サイズでの実験（スケールモデル実験）を可能とする磁気 セイル地上シミュレータを構築している.

3.1 スケール則 直径 $2.5 \mathrm{~m}$ の真空チャンバー内にお いて, チャンバー壁面との干渉を無視できる太陽風プラズ マ流のサイズは直径 $1 \mathrm{~m}$ 程度が限界である。このとき, 磁 気圈の大きさ $L$ に比べて十分に太陽風の径が大きい必要が あることから, 磁気圈の大きさは $0.1 \mathrm{~m}$ 程度として, 以下 のスケール則により太陽風パラメータを決定した。

太陽風プラズマと磁場の干渉により, 荷電粒子は $u \times B$ のローレンツカによってイオン・電子それぞれ逆の方向に 曲げられ第 3 図に示すような磁気圈境界面電流が流れる領 域を形成する。この電流が流れている領域は, 理想的には 電磁波の遮へい距離を意味する skin depth

$$
\delta=\frac{c}{\omega_{\mathrm{pe}}}
$$

程度の厚さを持つとされる. $c$ は光速, $\omega_{\mathrm{pe}}$ は電子プラズマ 周波数である。実際には, 地球磁気圈境界面の観測で指摘 されているように, 磁気圈境界面は skin depth $\delta$ よりも大 きく広がっている可能性がある。磁気圈境界面に侵入した 太陽風イオンと電子は電子に比べ質量の大きいイオンが電 子よりも深く磁気圈に侵入することで, 荷電分離が生じ外 向きの電場を生成する。このような電子がイオンよりも少 ない部分をシースと呼び, シースの厚さは磁気圈境界面に おけるイオン Larmor 半径

$$
r_{\mathrm{Li}}=\frac{m_{\mathrm{i}} u_{\mathrm{sw}}}{e \cdot 2 B_{\mathrm{mp}}}
$$

程度まで広がると予想されている， $e$ は電気素量, $B_{\mathrm{mp}}$ は 磁気圈境界面における磁場強度である。第 1 表にまとめた 太陽風パラメータから宇宙空間での $r_{\mathrm{Li}}$ は $72 \mathrm{~km}$ となる. 太陽風動圧とコイル磁気圧の釣り合い式から $B_{\mathrm{mp}}$ は以下 のように求まる。

$$
B_{\mathrm{mp}}=\sqrt{2 \mu_{0} n m_{\mathrm{i}} u_{\mathrm{sw}}^{2}}
$$

磁気圈によるプラズマの反射を十分活用するためにはこれ ら skin depth とイオン Larmor 半径が磁気圈の大きさに比 べて十分小さく,

$$
\begin{aligned}
& \frac{\delta}{L} \ll 1 \\
& \frac{r_{\mathrm{Li}}}{L} \ll 1
\end{aligned}
$$

\begin{tabular}{|c|c|c|c|}
\hline \multicolumn{4}{|c|}{ 第 1 表 太陽風の特性 } \\
\hline & $\begin{array}{l}\text { 速度 } \\
\text { 流速 } \\
\text { 温度 } \\
\text { マッハ数 } \\
\text { 磁気レイノルズ数 }\end{array}$ & $\begin{array}{c}300 \sim 500 \mathrm{~km} / \mathrm{s} \\
2 \sim 5 \times 10^{6} / \mathrm{m}^{3} \\
20 \mathrm{eV} \\
4 \sim 7 \\
10^{15} \\
\end{array}$ & \\
\hline \multicolumn{4}{|c|}{ 第 2 表＼cjkstart磁気セイルのスケーリング } \\
\hline & & $\begin{array}{c}\text { 磁気セイル } \\
\text { 実機 }\end{array}$ & $\begin{array}{c}\text { 実験室モデル } \\
\text { 設計値 }\end{array}$ \\
\hline $\begin{array}{l}\text { 磁気圈サイノ } \\
\text { 推力, } F\end{array}$ & 代表長)，L & $\begin{array}{c}20 \sim 100 \mathrm{~km} \\
1 \sim 40 \mathrm{~N}\end{array}$ & $\begin{array}{c}<0.1 \mathrm{~m} \\
<1 \mathrm{~N}\end{array}$ \\
\hline Larmor 半往 & 圣代表長比, $r_{\mathrm{Li}} / L$ & $0.1<r_{\mathrm{Li}} / L<3$ & $0.1<r_{\mathrm{Li}} / L<3$ \\
\hline 磁気圈厚さ1 & 戈表長比， $\delta / L$ & $<0.1$ & $<0.3$ \\
\hline 磁気レイノ) & レズ数, $R_{\mathrm{m}}$ & $>10^{8}$ & $3 \sim 15$ \\
\hline イオンマッノ & 数, $M_{\mathrm{i}}$ & 8 & $1 \sim 5$ \\
\hline
\end{tabular}

であることが望ましい. $1 \mathrm{~N}$ の推力を発生する磁気圈の大 きさ $L=20 \mathrm{~km}$ に対して，太陽風プラズマでは $\delta \sim 1 \mathrm{~km}$ であるから，(6) 式が成立する。 しかし， $r_{\mathrm{Li}}=72 \mathrm{~km}$ であ ることから

$$
\frac{r_{\mathrm{Li}}}{L} \sim 3.1
$$

となる.つまり, $r_{\mathrm{Li}} / L \ll 1$ の条件とはならないため, $L=$ $20 \mathrm{~km}$ 程度の磁気圈サイズでは磁気圈内にイオンが深く侵 入してくることによって太陽風の運動量の推力への変換効 率が下がることが予想される.

この他の無次元数として, 磁気レイノルズ数とマッハ数

$$
\begin{aligned}
& R_{\mathrm{m}}=\sigma \mu_{0} u_{\mathrm{sw}} L \\
& M_{\mathrm{i}}=\frac{u_{\mathrm{sw}}}{\sqrt{\gamma R T_{\mathrm{sw}}}}
\end{aligned}
$$

を表す。本実験では， $L=20 \sim 100 \mathrm{~km}$ の磁気セイルを想 定し, $0.1<r_{\mathrm{Li}} / L<3$ の条件とした. 実機と実験室モデル のスケーリングを第 2 表にまとめた。 磁気レイノルズ数 $R_{\mathrm{m}}$ のみ大きく異なる。 $R_{\mathrm{m}}$ は誘導電流の流れやすさを表すこ とから, 磁気セイル実験においては推力を低下させる方向 に寄与すると予想されるが， $R_{\mathrm{m}}$ をどの程度まで大きくす る必要があるかについては今後追求する必要がある.

3.2 磁気セイル地上シミュレータ 実験室サイズでの実 験を行うため, 直径 $2.5 \mathrm{~m}$ のスペースチャンバーに, 太陽 風シミュレータ (Solar Wind Simulator, SWS), 磁気セ イルシミュレータ (Magnetic Sail Simulator, MSS) から なる磁気セイル地上シミュレータを構築した. SWS には作 動ガスを水素とした MPD（Magneto-Plasma-Dynamic） アークジェットを用いた. MSS は $\phi 50 \mathrm{~mm}, 20$ ターンのソ レノイドコイルである (第 4 図)。これらの装置は 2 台の Pulse Forming Network（PFN）電源によって電力が供給 され，コントロール信号による同期により準定常動作を行 う. 各装置の通電波形 (第 5 図) からわかるように, 半值幅 $0.8 \mathrm{~ms}$ の定常動作である. 本実験での模擬太陽風プラズマは 流速 $38 \pm 7 \mathrm{~km} / \mathrm{s}$, 数密度 $1.2 \times 10^{19} \pm 4.7 \times 10^{17} \mathrm{~m}^{-3}$ で あり, 電離度 0.3 程度である. MSS はプラズマプルームが 一様になる SWS 出口から $600 \mathrm{~mm}$ 下流に設置し, その位 


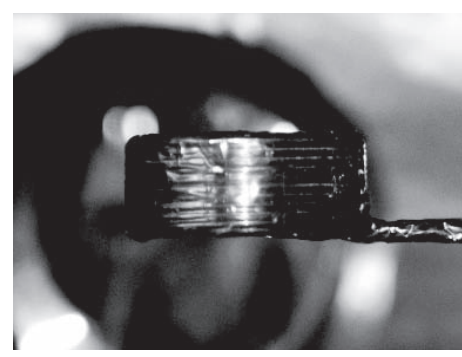

第 4 図 実験で用いた磁気セイル実験室モデル (半径 $25 \mathrm{~mm}-20$ 巻ソレノイドコイル)

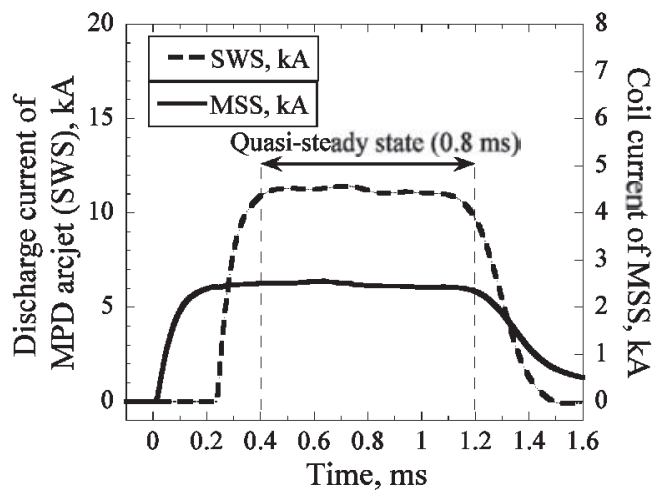

第 5 図 各シミュレータの通電電流波形 (SWS 充電電圧 : $4.0 \mathrm{kV}$, MSS 充電電圧 : $1.5 \mathrm{kV}$ )

第 3 表 模擬太陽風と磁気セイルコイルの特性

\begin{tabular}{ll}
\hline 模擬太陽風 & 水素 \\
作動ガス & $11 \mathrm{kA}$ (充電電圧 $4 \mathrm{kV})$ \\
放電電流 & $38 \pm 7 \mathrm{~km} / \mathrm{s}$ \\
プラズマ速度 & $1.2 \times 10^{19} \pm 4.7 \times 10^{17} \mathrm{~m}^{-3}$ \\
プラズマ数密度 & $0.9 \mathrm{eV}$ \\
電子温度 & $0.8 \mathrm{~ms}$ \\
作動時間 & 半径 $25 \mathrm{~mm}, 20$ 巻 \\
\hline 磁気セイルコイル & $0.3 \mathrm{kA}(0.25 \mathrm{kV}), 0.016 \mathrm{mTm}^{3}$ \\
コイル電流(充電電圧) & $0.7 \mathrm{kA}(0.50 \mathrm{kV}), 0.033 \mathrm{mTm}^{3}$ \\
磁気モーメント & $1.0 \mathrm{kA}(0.75 \mathrm{kV}), 0.050 \mathrm{mTm}^{3}$ \\
& $1.3 \mathrm{kA}(1.00 \mathrm{kV}), 0.066 \mathrm{mTm}^{3}$ \\
& $1.7 \mathrm{kA}(1.25 \mathrm{kV}), 0.082 \mathrm{mTm}^{3}$ \\
& $2.0 \mathrm{kA}(1.50 \mathrm{kV}), 0.099 \mathrm{mTm}^{3}$ \\
作動時間 & $0.9 \mathrm{~ms}$ \\
\hline
\end{tabular}

置でのプルーム径は半值幅で直径 $0.7 \mathrm{~m}$ である。各装置の 特性を第 3 表にまとめる.

スペースチャンバーは 1 基のターボ分子ポンプと 2 基の クライオポンプによって真空排気され, SWS 動作前の真空 度は $5 \times 10^{-3} \mathrm{~Pa}$ 以下に保たれた。

\section{4. 推力測定方法}

磁気セイルの推力計測には, 振り子式スラストスタンド を用いたインパルス計測から推力を求める方法を採用した. 本実験装置は約 $1 \mathrm{~ms}$ の準定常動作であり，測定したインパ ルスを装置の動作時間で割ることで, 生じた力が求まる.

実験装置の概略図を第 6 図に示す。スラストスタンドは太 陽風流れと同一方向にのみ摇れるよう, 長さ $1 \mathrm{~m}$, 幅 $20 \mathrm{~mm}$

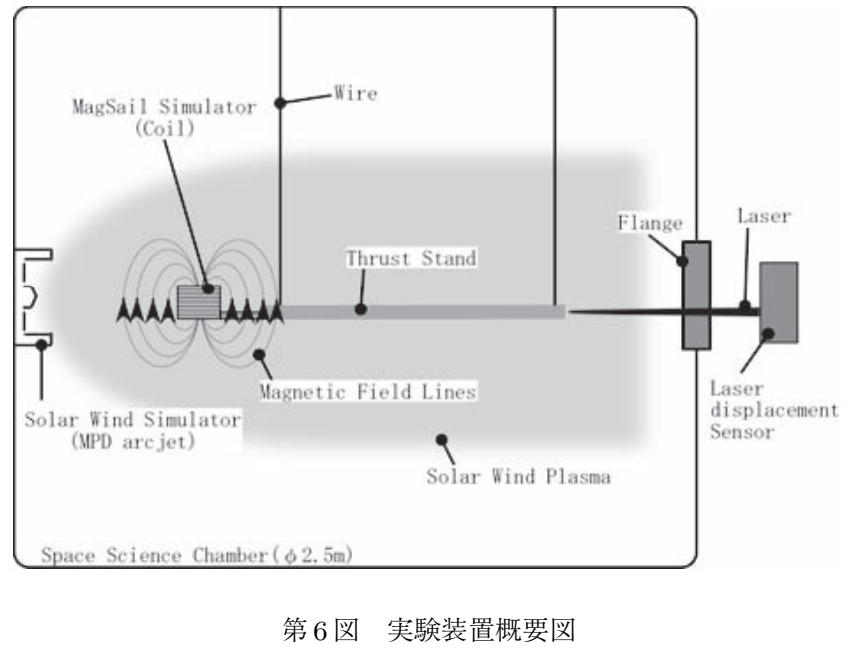

のアルミ材を使用し，真空チャンバーの天井から 4 本のス テンレスワイヤーによって吊り下げ，スラストスタンドの 変位は後方のガラスフランジを通してチャンバー外に設置 したレーザー変位計によって計測を行った，スラストスタ ンドはシミュレータ動作時間よりも長い約 $1.5 \mathrm{~s}$ の周期で 振動し, 加えられた力積に比例した振幅で摇れる. 単振り 子を用いて既知の力積をスラストスタンドに与えることで 校正を行い, スラストスタンドの最初の最大振幅を比較し, 変位から力積を得る。コイルはスラストスタンドから前方 に突き出すように設置し，スラストスタンドによるコイル 周囲の流れへの影響を抑えている.

本スラストスタンドに生じる力には, 推力であるコイル に生じる電磁力以外に, 太陽風プラズマの衝突によるもの, そして，太陽風とともに到来する中性粒子の衝突によるも のがある，そのため，コイルに生じる電磁力による力のみ を評価するために推力は以下のように求めた。

$F_{\text {Magsail }}=\frac{(F \Delta t)_{\text {Magsail }}}{\Delta t}=\frac{(F \Delta t)_{\text {total }}-(F \Delta t)_{\mathrm{SWS}}}{\Delta t}$

ここで $F_{\text {Magsail }}$ は推力 (電磁力), $\Delta t$ はシミュレータ動作時 間 $0.8 \mathrm{~ms},(F \Delta t)_{\text {Magsail }}$ は磁気セイルの力積, $(F \Delta t)_{\text {total }}$ は太陽風・中性粒子と磁場・コイル・スラストスタンドと の干渉による力積, $(F \Delta t)_{\mathrm{SWS}}$ は磁場非生成時に太陽風・ 中性粒子がコイルとスラストスタンドと干渉して生じる力 積である。計測される $(F \Delta t)_{\mathrm{SWS}}$ には, 太陽風プラズマ のコイルへの衝突による寄与分が含まれているのに対し, $(F \Delta t)_{\text {total }}$ では, 磁気圈形成によりプラズマのコイルへの 衝突は減少している。そのため, 式 (11) を用いて得た推力 は実際の推力を過小評価している.

各シミュレータ動作時のスラストスタンドの振動の様子 を図に示す、第 7 図において $0.6 \mathrm{~mm}$ の最大振幅を示して いるのが太陽風一磁場干渉によって生じた力を含む場合の変 位波形である. 次に $0.2 \mathrm{~mm}$ の振幅を示しているのがコイ ルとスラストスタンドに生じる太陽風の圧力による力積で 生じた変位を, そして振動が遅れて始まっている波形がコ イルに通電することで生じる振動である。このコイル通電 


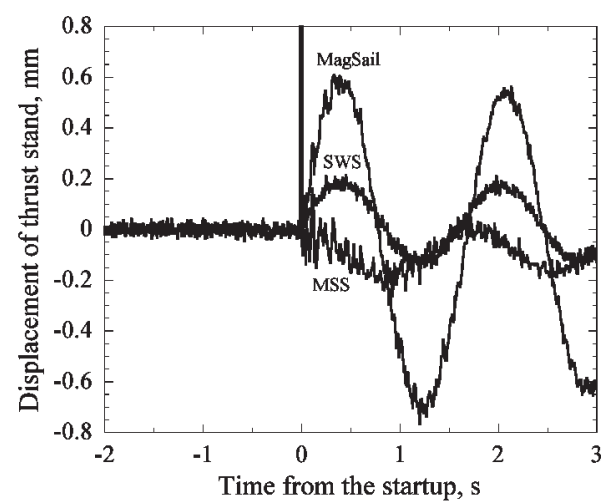

第 7 図 各シミュレータ動作時のスラストスタンド変位波形 (SWS 充 電電圧： $4.0 \mathrm{kV}$, MSS 通電電流 (コイル電流) : $2.0 \mathrm{kA}$ )

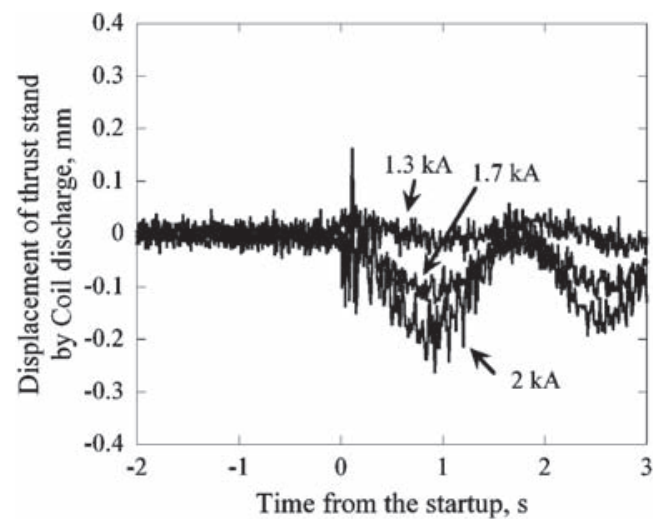

第 8 図 各コイル通電電流值により生じるスラストスタンドの変位

時に生じる振動は電力供給ケーブルを流れる電流の往還に よって生じるものであり，第 8 困に示すように通電電流值 が大きくなるほど振動が顕著に現れる。この振動は計測時 におけるゼロ点のエラーとして，エラーバーに含めた

\section{5. 実験結果と考察}

5.1 磁気セイル周囲の可視化 シャッターカメラによる 撮像結果を第 9 図に示す. (a) はコイル電流 $0 \mathrm{kA}$ の流れ場 の様子を示すが，コイル前面にわずかに発光が見られる程 度である。コイル電流を $1.0,1.7,2.5 \mathrm{kA}$ と変化させるこ とで，コイル前方に弓状の暗部が観測された。コイル電流 を流さない(a)の場合ではこのような流れ場が観測されな いことから，これはコイル電流が作る磁場と太陽風プラズ マとの干渉によって生じたと考えられる. 次に, コイル中心 から暗部中心までの距離を計測すると，96, 119, $136 \mathrm{~mm}$ とコイル電流の増加, すなわちコイル磁場の増大に合わせ て距離が拡大していることがわかる。よって，観測された コイル周囲の流れ場の変化は, コイル磁場と太陽風流れの 干渉の大きさを示していることがわかる.

5.2 コイル周囲の磁場変化 磁気プローブによるコイル 中心から太陽風上流方向へのコイルダイポール磁場 $B_{0}$ の 分布と, 太陽風と干渉時の磁場 $B^{\prime}$ の分布を第 10 図 (a) に 示す.この $B^{\prime}$ を $B_{0}$ で規格化した各電流值における磁場分 布を第 10 図 (b) に示す。各コイル電流值において, コイル

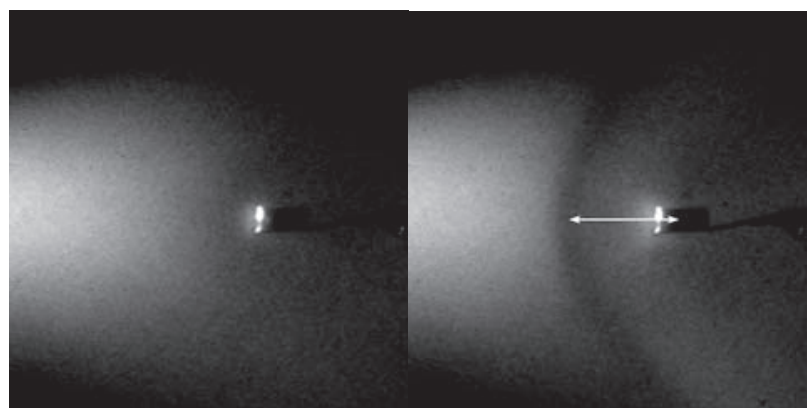

(a) コイル電流 $0 \mathrm{kA}$

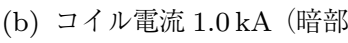
中心までの距離 : $96 \mathrm{~mm}$ )

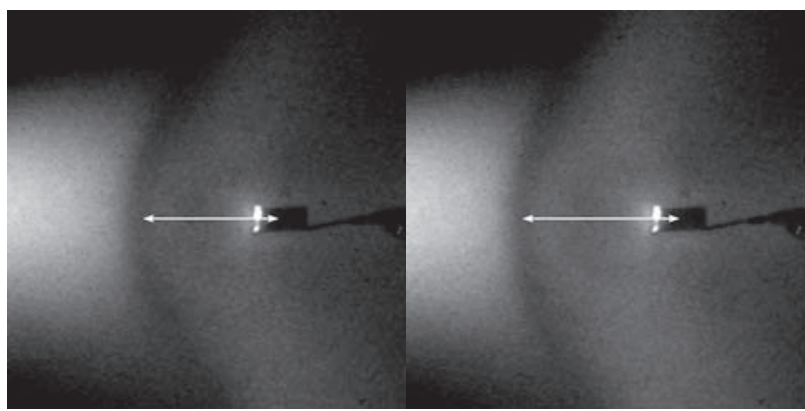

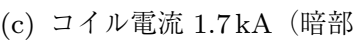
中心までの距離：119 mm）

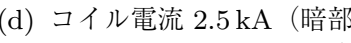
中心までの距離: $136 \mathrm{~mm}$ )

第 9 図 磁気セイル周りの流れ（MSS：太陽風噴射口から $600 \mathrm{~mm}$, コイル電流 $1.0,1.7,2.5 \mathrm{kA})$

近傍は磁束密度が増加し, その後急激に減少している。 こ れはコイル磁場による磁気圧と太陽風動圧が釣り合う位置 において，イオンと電子の Larmor 運動の方向が異なるた めに生じる境界面電流によって磁場が誘起され, その磁場 が境界面より内側ではコイル磁場を強める向きに，外側で は弱める向きに作用するためである。地球磁気圈の観測で はこの誘導磁場によって地磁気の 2 倍程度まで磁気圈境界 面内側で磁場強度が増大していることが知られており, 本 実験でも 1.4 倍までの増大が確認できる。このように地球 磁気圈と同様の構造が観測されたことから, 磁気圈境界面 の位置は境界面電流の流れる位置, すなわち, 元のコイル 磁場と同強度の磁場が観測された位置となる。計測結果か ら，0.1，0.12，0.13 m の位置が磁気圈境界であり，コイル 電流を増大し, 磁気モーメントを制御することで, 磁気圈 サイズの制御が可能であることが明らかになった。

5.3 インパルス計測結果と推力 インパルス計測の結果 を第 11 図に示す。コイル磁場を生成していない状態で，太 陽風のみがコイルとスラストスタンドに衝突したとき，ス ラストスタンドには $0.59 \mathrm{mNs}$ のインパルスが発生した. 次 に $0.32 \mathrm{kA}$ の電流を流し, $0.02 \mathrm{mTm}^{3}$ の磁気モーメントの コイル磁場に対して太陽風を供給した場合, スタンドに生 じるインパルスは $0.77 \mathrm{mNs}$ となった。この差分 $0.18 \mathrm{mNs}$ が磁場セイルの推力としてコイルに生じたインパルスであ る.よって, 太陽風が供給されている時間 $(\Delta t=0.8 \mathrm{~ms})$ で割ることで磁気セイル推力は $F=0.47 \mathrm{~N}$ であることが わかる。このとき，コイルに電流を流すだけでもスラスト 


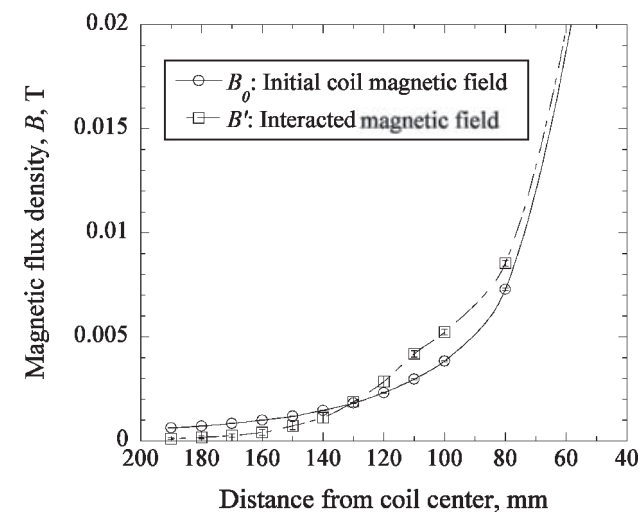

（a）太陽風との干渉前後の磁場分布（MSS:太陽風噴射口から $600 \mathrm{~mm}$, コイル電流 $1.7 \mathrm{kA}$ ，コイル表面は $50 \mathrm{~mm}$ の位置)

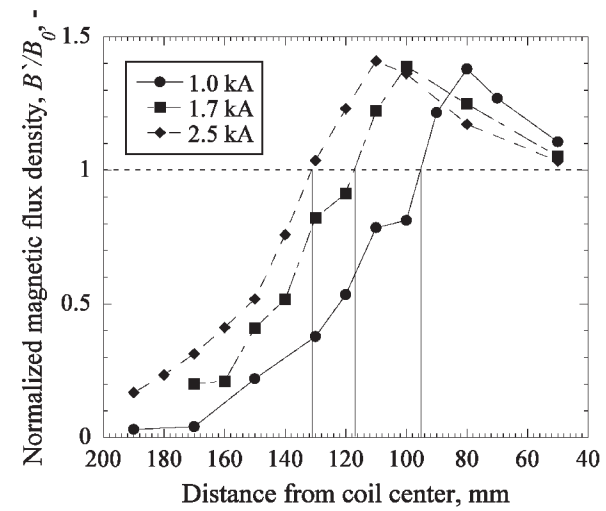

（b）干渉前の磁場（コイル磁場）で規格化した干渉後の磁場分布 （MSS:太陽風噴射口から $600 \mathrm{~mm}$ ，コイル電流 1.0, 1.7, $2.5 \mathrm{kA}$ )

第 10 図 太陽風一コイル線上におけるコイルダイポール方向磁場

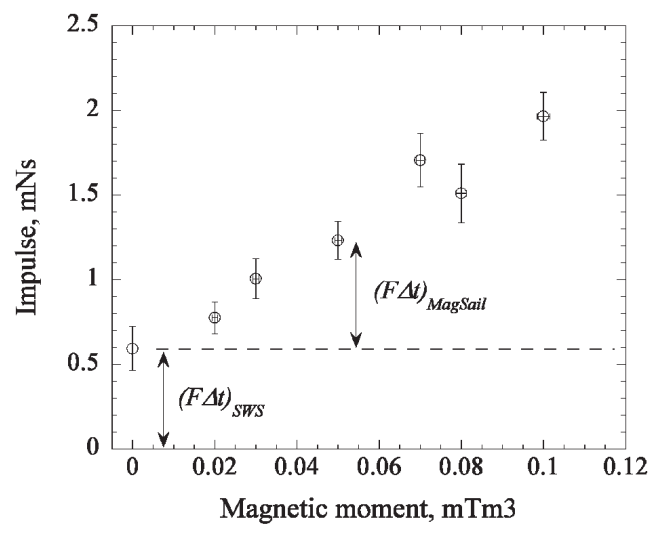

第11図 各磁気モーメントにおいてスラストスタンドで計測された インパルス（MSS：太陽風噴射口から $600 \mathrm{~mm}$ ，コイル電 流 $0 \sim 2.0 \mathrm{kA}$ )

スタンドにインパルスが生じる。これを通電ノイズとして 推力值のエラーに含めた。 推力計測結果を第 12 図に示す. 磁気モーメントが $0.1 \mathrm{mTm}^{3}$ のとき, 最大推力 $1.9 \mathrm{~N}$ が得 られた。コイル電流を増加し, 磁気モーメントを増大させ ることで, 推力が増加していることがわかる.これは撮像 と磁場計測結果からわかるように, コイル電流を増大させ,

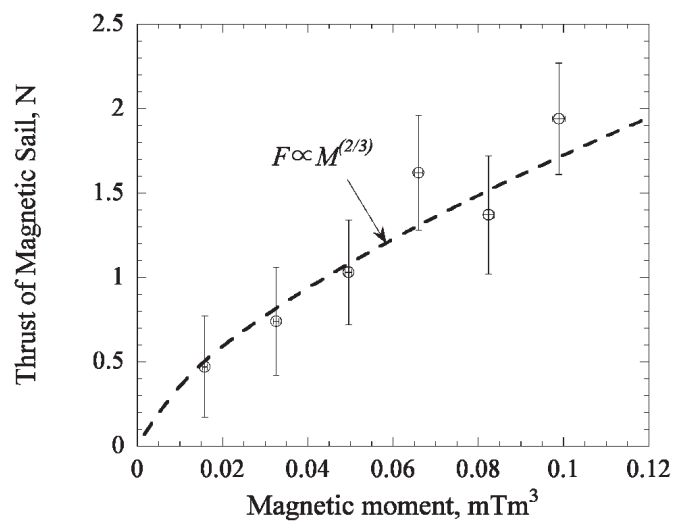

第12図 磁気モーメントと磁気セイル推力の関係（MSS：太陽風噴 射口から $600 \mathrm{~mm}$ ，コイル電流 $0.3 \sim 2.0 \mathrm{kA}$ )

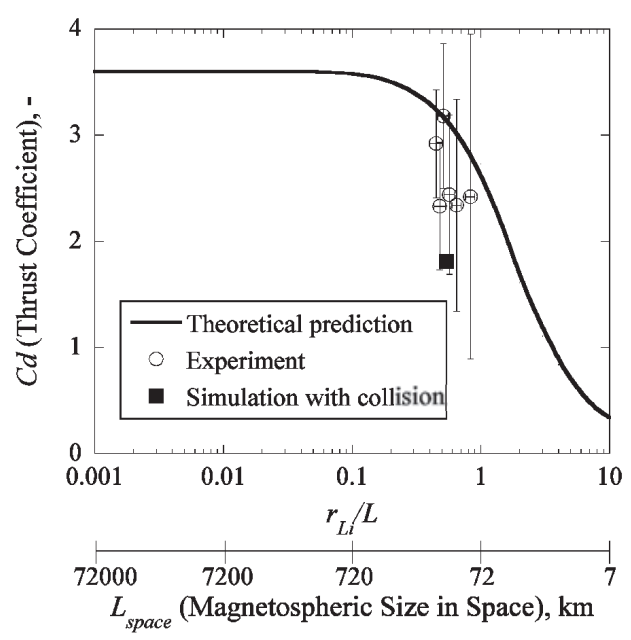

第 13 図 推力係数の実験值と理論計算值, および衝突を考慮した計 算結果との比較 6,17$)$

磁気モーメントを変化させることで, 磁気圈が拡大し, よ り大きな推力が得られることを示している。第 12 図中に示 した点線は式 (1) および (2) から推力が磁気モーメントの $2 / 3$ 乗に比例することから引いた線である．点線が実験值 がよく一致しており, 本結果が磁気モーメントを増加させ ることで磁気圈サイズ $L$ が大きくなることを示している.

5.4 推力の評価 本実験結果の実機スケールとの相関 について考える. 本実験でのイオン Larmor 半径は $r_{\mathrm{Li}}=$ $0.06 \mathrm{~m}$ である. 磁気モーメント $0.05 \mathrm{mTm}^{3}$ のとき, 磁場 計測から磁気圈サイズ $L=0.09 \mathrm{~m}$ であり，イオン Larmor 半径代表長比は $r_{\mathrm{Li}} / L=0.7$ となる. 実際の宇宙空間を模 擬した計算から，イオン Larmor 半径代表長比が $0.1 よ り$ 大きいスケールの磁気セイルでは, 太陽風が磁気圈内深く 侵入するため, 推力係数が小さくなる ${ }^{6)}$. 比較のために本 実験結果の推力係数を第 13 図に示す.

推力係数の実験值がハイブリッド粒子モデル（イオン粒 子/電子流体）による数值解析による予測值より小さい值で あるのは, 数值解析による予測值は実際の宇宙空間での磁 気セイルを模擬しているため, 太陽風を無衝突プラズマと して扱っているのに対し, 実験では電離度の影響で中性粒 
子との衝突の影響が含まれていること, そして, 推力評価 を行う際に，推力を過小評価するような評価式（式 (11)) を用いているためである。衝突を考慮した条件での実験室 実験を模擬した数值解析では電離度 0.3 で $C_{\mathrm{d}}=1.8$ とな ることが明らかにされている17)。本実験での電離度も 0.3 程度であり, エラーバーが大きいものの, 理論計算や衝突 を考慮した数值シミュレーションに近い $C_{\mathrm{d}}$ 值を示してい るのは妥当であろう.

本結果を考慮して $r_{\mathrm{Li}} / L \sim 1$ での実機性能を予測する. 太 陽から $1 \mathrm{AU}$ において, 磁気圈境界でのイオン Larmor 半 径は約 $72 \mathrm{~km}$ であり, 本実験が模擬したイオン Larmor 半 径代表長比 $r_{\mathrm{Li}} / L=0.86$ のとき, 実機スケールでは磁気 圈サイズ $L=84 \mathrm{~km}$ の人工磁気圈を宇宙機周りに形成し ていることになる。この磁気圈を形成するために必要な磁 気モーメントは式 $(2)$ から $2 \times 10^{8} \mathrm{Tm}^{3}$ であり, H-IIB口 ケットで打ち上げ可能な直径 $4 \mathrm{~m}$ のコイルを想定した場合, $1 \times 10^{13} \mathrm{AT}$ の起磁力が必要となる. 実証機での利用を考 えている高温超伝導線材を用いた場合, 通電電流は $200 \mathrm{~A}$ 程度であることから, $7 \times 10^{10}$ 巻ものコイルが必要となる. コイル線材の重量を $1 \mathrm{~g} / \mathrm{m}$ としても 900 トンとなるため, 実現は難しい. しかしながら, 磁気セイルの磁場をプラズ マ噴射で拡大する磁気プラズマセイルによって本実験が明 らかにしたサイズの磁気圈を形成できれば $30 \mathrm{~N} も の$ 推力 が得られるはずであり, 磁気プラズマセイルによってどの 程度磁場を拡大できるかが鍵となる。

\section{6. ま め}

太陽風とコイル磁場の干渉を利用して推力を得る磁気セ イルの推力特性を明らかにするために, JAXA 宇宙科学研 究所のスペースサイエンスチャンバーに構築した磁気セイ ル地上シミュレータを用いたスケールモデル実験を行った.

磁気セイル周りの流れの可視化と磁場計測から, コイル 磁気モーメントを变化させることで, 磁気圈サイズが変化 することを明らかにし, また, 推力計測の結果から磁気圈サ イズに応じた推力が生じることを明らかにした。磁気モー メント $0.013 \mathrm{mTm}^{3}$ において, 磁気圈サイズが $0.07 \mathrm{~m}$, そ のときの推力は $0.47 \mathrm{~N}$ であった，実験結果から得られた推 力係数を介して, 宇宙空間における磁気セイル実機の性能 に換算すると, $84 \mathrm{~km}$ の磁気圈サイズを形成し, $30 \mathrm{~N}$ の推 力を得ることが可能である. 磁気セイル単体では, 搭載用 コイル重量が非常に大きくなってしまうことから現実的で はない.このため, 今後は磁気セイル磁気圈をプラズマ噴 射によって拡大する磁気プラズマセイルによって, 同サイ ズの磁気圈をより小さな磁気モーメントのコイルで達成す る技術の開発が望まれる。

本研究にご協力いただいた磁気プラズマセイルワーキン ググループのメンバー，特に計算データを提供していただ いた梶村好宏先生に深く感謝いたします。本研究は科学研 究費補助金（基盤研究 (A)(No. 21246126)）, JAXA 宇宙 科学研究所 (宇宙工学委員会ならびにスペースプラズマ専
門委員会), 科学技術振興機構（戦略的創造推進事業）の支 援を受けて, JAXA 宇宙科学研究所内のスペースプラズマ 研究設備にて実施した.

\section{参 考 文 献}

1) Andrews, D. G. and Zubrin, R. M.: Magnetic Sails and Interstellar Travel, J. Br. Interplanetary Soc., 43 (1990), pp. 265-272.

2) Zubrin, R. M. and Andrews, D. G.: Magnetic Sails and Interplanetary Travel, J. Spacecraft Rockets, 28 (1991), pp. 197-203.

3) Zubrin, R. M.: The Use of Magnetic Sails to Escape from Low Earth Orbit, J. Br. Interplanetary Soc., 46 (1993), pp. $3-10$.

4) Winglee, R. M., Slough, J., Ziemba, T. and Goodson, A.: Mini-Magnetospheric Plasma Propulsion: Tapping the Energy of the Solar Wind for Spacecraft Propulsion, J. Geophys. Res. Space Phys., 105 (2010), pp. 21067-21077.

5) Akita, D. and Suzuki, K.: Kinetic Analysis on Plasma Flow of Solar Wind around Magnetic Sail, AIAA Paper 2005-4791, 36th AIAA Plasmadynamics and Lasers Conference, 2005.

6) Fujita, K.: Particle Simulation of Moderately-Sized Magnetic Sails, J. Space Technol. Sci., 20 (2004), pp. 26-31.

7) Nishida, H., Ogawa, H., Funaki, I., Fujita, K., Yamakawa, H. and Nakayama, Y.: Two-Dimensional Magnetohydrodynamic Simulation of a Magnetic Sail, J. Spacecraft Rockets, 43 (2006), pp. 667-672.

8) Kajimura, Y., Funaki, I., Shinohara, I., Usui, H. and Yamakawa, H.: Thrust Evaluation of Magneto Plasma Sail by Using Three-Dimensional Hybrid PIC Code, 46th AIAA/ASME/SAE/ASEE Joint Propulsion Conference \& Exhibit, 2010.

9) Usui, H., Kajimura, Y., Nunami, M., Funaki, I., Shinohara, I., Yamakawa, H., Nakamura, M., Akita, D. and Ueda, H. O.: Multi-Scale Plasma Particle Simulation for the Development of Interplanetary Flight System, J. Plasma Fusion Res., 8 (2009), pp. 1569-1573.

10) Winglee, R. M., Euripides, P., Ziemba, T., Slough, J. and Giersch, L.: Simulation of Mini-Magnetospheric Plasma Propulsion (M2P2) Interacting with an External Plasma Wind, AIAA Paper 2003-5224, 39th AIAA/ASME/SAE/ASEE Joint Propulsion Conference \& Exhibit, 2003.

11）船木一幸, 小嶋秀典, 山川 宏, 清水幸夫, 都木恭一郎, 中山宜 典, 藤田和央, 小川博之, 篠原季次 : 磁気セイルシミュレータの 開発, 日本航空宇宙学会論文集, 54 (2006), pp. 501-509.

12) Funaki, I., Yamakawa, H., Shimizu, Y., Nakayama, Y., Horisawa, H., Ueno, K. and Kimura, T.: Experimental Simulation of Magnetic Sails, AIAA Paper 2006-5227, 42nd AIAA/ASME/SAE/ASEE Joint Propulsion Conference \& Exhibit, 2006.

13) Funaki, I., Kojima, H., Yamakawa, H., Nakayama, Y. and Shimizu, Y.: Laboratory Experiment of Plasma Flow around Magnetic Sail, Astrophys. Space Sci., 307 (2007), pp. 63-68.

14) Ueno, K., Kimura, T., Ayabe, T., Funaki, I., Yamakawa, H. and Horisawa, H.: Thrust Measurement of Pure Magnetic Sail, Trans. JSASS Space Tech. Japan, 7 (2009), pp. Pb_65Pb_69.

15) Ueno, K., Funaki, I., Kimura, T., Horisawa, H. and Yamakawa, H.: Thrust Measurement of Pure Magnetic Sail Using Parallelogram-Pendulum Method, J. Propul. Power, 25 (2009), pp. 536-539.

16) 大林辰蔵: 宇宙空間物理学, 裳華房, 東京, 1970, pp. 181-182.

17) Kajimura, Y., Usui, H., Funaki, I., Ueno, K., Nunami, M., Shinohara, I., Nakamura, M. and Yamakawa, H.: Hybrid Particle-in-Cell Simulations of Magnetic Sail in Laboratory Experiment, J. Propul. Power, 26 (2010), pp. 159-166. 